\title{
A novel radiological proximal femoral angles facilitate peritrochanteric surgery
}

\section{Radyolojik yeni proksimal femur açıları peritrokanterik cerrahide cerrahlara yardımcı olabilir}

\author{
Nihat Acar ${ }^{1}$, Ahmet A. Karaarslan²
}

Catalca ilyas cokay hospital, Department of Orthopaedics and Traumatology, postalcode 34540, Catalca-Istanbul-Turkey

${ }^{2}$ Batı Anadolu Central Hospital, Department of Orthopedics and Traumatology, Bayraklı, postalcode 35100, Izmir-Turkey.

Corresponding author: Nihat ACAR, Catalca ilyas cokay hospital, Department of Orthopaedics and Traumatology, Catalca-Istanbul-Turkey

E-mail: zenanacar@gmail.com

Received/Accepted: May 14, 2016 / January 04, 2017

Conflict of interest: There is not a conflict of interest.

\section{SUMMARY}

Objective: The geometry of the proximal femur has gained very much attention in the last decade. Many radiological measures have been introduced to help radiologists and orthopaedic surgeons to evaluate surgeries, diagnose diseases and plan for surgical interventions. The main purpose of this study was to assess the validity of a novel radiological land marks and angles to help in Dynamic Hip screw (DHS) application surgery in the proximal femur.

Method: 200 true hip anteroposterior radiographs were obtained for patients between ages 50 to 80 years. We have developed the lesser trochanteric fovea capitis angle (LTFCA) and the lesser trochanteric lateral cortex angle (LTLFCA). Patients were divided into two groups, the male group $(n=100)$ and the female group $(n=100)$. The LTFCA + LTLFCA were assessed in the left and right hips in both genders.

Results: In male population, the average LTFCA + LTLFCA values for the right and left hip joints were $\left(133.2^{\circ} \pm 5.27\right.$, $\left.134.5^{\circ} \pm 4.92\right)$ respectively. There was no statistical difference between both sides, $p=0.74$. Whereas in female population, the average LTFCA + LTLFCA values for the right and left hip joints were $\left(134.8^{\circ} \pm 6.13,135.6^{\circ} \pm 5.45\right)$ respectively. No statistical significance was detected between the two sides, $\mathrm{p}=0.37$.

Conclusions: The LTFCA is an easy method that can facilitate trustable radiological land marks for surgeons for proper DHS insertion. Further studies should be conducted to evaluate the sensitivity and specificity of the lesser trochanteric fovea capitis angle (LTFCA) and its validity in proximal femoral surgery.

Keywords : Proximal femoral geometry; dynamic hip screw; lesser trochanteric fovea capitis angle

\section{ÖZET}

Amaç: Proksimal femur geometrisine olan ilgi son on yılda oldukça artmıştır. Hastalıklara tanı koymak, yapılacak cerrahiyi planlamak, yapılan ameliyatları değerlendirmek ve radyologlara ve ortopedistlere yardımcı olmak gayesi ile birçok radyolojik ölçüm yöntemi bildirildi. Proksimal femurda dinamik kalça vidası (DHS) cerrahi uygulamasına yardımcı yeni radyolojik işaret ve açıların geçerliliğini değerlendirmek bu çalışmanın ana amacıdır.

Yöntem: Yaşları 50 ile 80 yaş arası hastalardan çekilen 200 true kalça AP radyografisi çalışmaya alındı. Küçük trochanter fovea kapitis açısını (LTFCA) ve küçük trochanter lateral korteks açısını (LTLFCA) geliştirdik. Erkekler $(n=100)$ ve kadınlar $(n=100)$ olarak hastalar iki guruba ayrıldı. LTFCA + LTLFCA her iki cinste sağ ve sol kalçada ayrı ayrı değerlendirildi.

Bulgular: Erkek topluluğunda ortalama LTFCA + LTLFCA değerleri sağ kalçada $133.2^{\circ} \pm 5.27$, sol kalçada $134.5^{\circ} \pm 4.92$ idi ve her iki taraf arasında istatistiki fark bulunmadı $(p=0.74)$. Kadın topluluğunda ortalama LTFCA + LTLFCA değerleri sağ kalçada $134.8^{\circ} \pm 6.13$, sol kalçada $135.6^{\circ} \pm 5.45$ idi ve her iki taraf arasında istatistiki fark bulunmadı $(\mathrm{p}=$ $0.37)$.

Sonuç: Küçük trochanter fovea kapitis açısı (LTFCA) uygun pozisyonda DHS çakılabilmesini kolaylaştıran güvenilir ve kolay bir yöntemdir. LTFCA nın duyarlılık ve özgüllüğünü ve proksimal femur cerrahisindeki geçerliliğini değerlendirmek için daha ileri çalışmalar yapılmalıdır.

Anahtar sözcükler: Proksimal femur geometrisi; dinamik kalça vidası; Küçük trochanter fovea kapitis açısı 


\section{INTRODUCTION}

The geometry of the proximal femur has gained very much attention in the last decade ${ }^{1}$. Many radiological measures have been introduced in the literature to help radiologists and orthopaedic surgeons to evaluate surgeries, diagnose diseases and plan for surgical interventions ${ }^{2,3}$. Nowadays and by the introduction of picture archiving and communication systems (PACS) which became widespread and the standard radiological viewing tool in many orthopaedic clinics, radiologists and orthopaedic surgeons became more able to measure angles and distances even in a more precise manner ${ }^{4,5}$.

Many works have been introduced in the literature focusing on the proximal geometry of the femur using cadaveric samples, $\mathrm{x}$-rays or computed tomography, demonstrated substantial differences in the proximal femoral geometry in different patient groups. Many radiological parameters have been described to aid in diagnosis and surgical intervention ${ }^{6,7}$.
We have developed the Lesser trochanteric fovea capitis angle to facilitate a more minimal invasive approach for dynamic hip screw (DHS) insertion and peritrochanteric surgery. The clinical results of minimal DHS using the new angle were compared to the clinical results using the conventional technique were evaluated ${ }^{12}$.

The main purpose of this study was to assess the variation of the novel radiological landmarks and angles between the right and left hip joints and different genders to constitute a guide line for surgeons who deal with proximal femoral surgery.

\section{MATERIAL AND METHOD}

Two-hundreds true hip anteroposterior radiographs were obtained for patients between ages 50 to 80 years (Table 1). This study was approved by the ethical committee of Dokuz Eylul faculty of medicine Hospital at $07 / 05 / 2015$ with a protocol number of 2070-GOA and decision number 2015/12-34.

Table 1 : Demographic data of patients involved in this study

\begin{tabular}{|c|c|c|c|c|c|}
\hline Gender & $\begin{array}{c}\text { Number } \\
\text { of patients }\end{array}$ & $\begin{array}{c}\text { Average } \\
\text { of age } \\
\text { (years) }\end{array}$ & $\begin{array}{c}\text { Standard } \\
\text { deviation } \\
\text { (SD) }\end{array}$ & $\begin{array}{c}\text { Range } \\
\text { (years) }\end{array}$ & P value \\
\hline Male & 100 & 63.93 & \pm 8.29 & $52-80$ & \multirow{2}{*}{0.38} \\
\hline Female & 100 & 62.24 & \pm 7.87 & $51-78$ & \\
\hline
\end{tabular}

The inclusion criteria in this study were; age between 50 to 80 years, no any previous hip surgery, no metabolic bone disease history, no history of hip dysplasia and no any hip associated pathologies. A total of 200 hip pelvis AP views were obtained for this study with 200 right hip and 200 left hip views.

The beam of the x-ray was directed toward the midline above the symphysis pubis with both lower extremities in $15^{\circ}$ of internal rotation. All radiograms were taken using the same standard radiographic positioning using the same radiographic machine (Philips Medical Systems, Digital Diagnost).

The patients were divided into two groups, the male and the female groups. Each group was composed of 100 patients AP pelvis X-rays and each group was subdivided into two subgroups the right and the left hips subgroups (Table 2). For statistical analysis the Mann-Whitney-U test was used, the level of significance was set as $p<0.05$. 
Table 2 : The average values of LTFCA + LTLFCA in both genders in left and right hip joints.

\begin{tabular}{|c|c|c|c|c|c|c|c|}
\hline $\begin{array}{c}\text { Values of } \\
\text { LTFCA + } \\
\text { LTLFCA }\end{array}$ & \multicolumn{3}{|c|}{ Male patients } & \multicolumn{3}{c|}{ Female patients } & $\begin{array}{c}\text { Both } \\
\text { genders }\end{array}$ \\
\cline { 2 - 8 } & $\begin{array}{c}\text { Right } \\
\text { hips }\end{array}$ & $\begin{array}{c}\text { Left } \\
\text { hips }\end{array}$ & $\begin{array}{c}\text { Gener } \\
\text { al }\end{array}$ & $\begin{array}{c}\text { Gener } \\
\text { al }\end{array}$ & $\begin{array}{c}\text { Right } \\
\text { hips }\end{array}$ & $\begin{array}{c}\text { Left } \\
\text { hips }\end{array}$ & General \\
\hline Average $\left(^{\circ}\right.$ ) & 133.2 & 134.5 & 133.8 & 135.2 & 134.8 & 135.6 & 134.5 \\
\hline SD \pm & 5.27 & 4.92 & 5.09 & 5.79 & 6.13 & 5.45 & 5.44 \\
\hline Min. $\left(^{\circ}\right.$ ) & 129.4 & 127.6 & 127.6 & 126.3 & 126.3 & 128.5 & 126.3 \\
\hline Max. ( ${ }^{\circ}$ ) & 138.7 & 137.5 & 138.7 & 141 & 139.2 & 141 & 141 \\
\hline P value & \multicolumn{3}{|c|}{0.74} & \multicolumn{3}{|c|}{0.08} & \multicolumn{3}{c|}{0.37} & \\
\hline
\end{tabular}

\section{Angle measurement}

The lesser trochanteric fovea capitis angle (LTFCA) is determined by drawing three lines and two angles on a true anteroposterior hip X-ray. The first line (line $\mathrm{X}$ ), is drawn parallel to the lateral cortex of the femoral shaft. The second line (line $\mathrm{Y}$ ), is drawn from the prominent tip of the lesser trochanter passing laterally and perpendicularly on the lateral cortex line (line X). The third line (line
$\mathrm{Z}$ ), is drawn from the intersection of line $(\mathrm{X})$ and line $(\mathrm{Y})$ on the lateral femoral cortex directed superiorly to the upper margin of the fovea capitis of the femoral head. The intersection of these three lines create two angles; the lesser trochanteric fovea capitis angle (LTFCA) and the lesser trochanteric lateral femoral cortex angle (LTLFCA) which is a right angle $\left(90^{\circ}\right)$ (Fig 1).

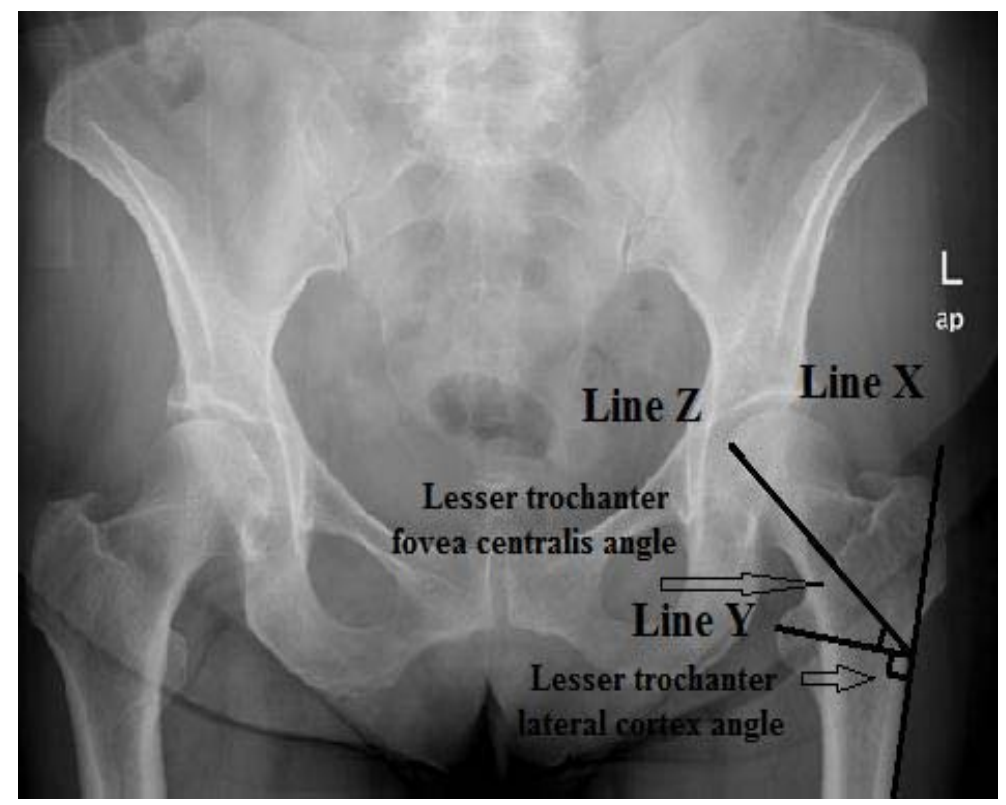

Figure 1: An anteroposterior pelvic X-ray for an intact proximal femur demonstrating the three lines and two angles required for a proper DHS insertion; line (a) is a line drawn on or parallel to the lateral femoral cortex, line (b) is a line drawn from the tip of the lesser trochanter perpendicular to line (a), line (c) is a line drawn from the intersection point of line (a) and line (b) to the upper margin of fovea capitis. Two formed angles shown by two arrows, the vertical arrow shows the lesser trochanteric lateral femoral cortex angle, which is a right angle and the horizontal arrow shows the lesser trochanteric fovea capitis angle (LTFCA). 


\section{RESULTS}

Two-hundreds true AP views of the pelvis for patients with an age ranging between 50-80 years, divided into two groups, the male group $(\mathrm{n}=100)$, with an average age of $63.93 \pm 8.29$ range (52-80) and the female group $(\mathrm{n}=100)$, with an average age of 62.24 \pm 7.87 range (51-78). There was no statistical significance between the two groups regarding the age with $\mathrm{p}=0.38$.

In the male population, the average LTFCA + LTLFCA values for the right and left hip joints were $\left(133.2^{\circ} \pm 5.27,134.5^{\circ} \pm 4.92\right)$ respectively. There was no statistical difference between both sides with $p=0.74$. Whereas in the female population, the average LTFCA + LTLFCA values for the right and left hip joints were $\left(134.8^{\circ} \pm 6.13\right.$, $\left.135.6^{\circ} \pm 5.45\right)$ respectively. No statistical significance was detected between the two sides with $\mathrm{p}=0.37$.

The general average values of the LTFCA + LTLFCA in the male and female populations were $\left(133.8^{\circ} \pm 5.09, \quad 135.2^{\circ} \pm 5.79\right)$ respectively. No statistical significance was detected between the two sides with $p=0.08$. The general average value of the LTFCA + LTLFCA in both genders and both sides was $134.5^{\circ} \pm 5.44$.

\section{DISCUSSION}

The design of the measurement method is stemmed from our extensive daily clinical practice and was aimed to help surgeons to provide an easy application and entrance of the dynamic hip screw (DHS) during peritrochanteric surgery of the proximal femur.

Many studies in the literature focused on the geometry of the proximal femur to help surgeons and implant manufacturers to build a data base regarding proximal femoral surgery ${ }^{8,9}$.

In a previous retrospective work we have studied and compared the clinical results of the minimal invasive DHS technique using the novel land mark methodology and the conventional technique. It had been demonstrated that, using this novel angle and landmarks produced even smaller incision than the well-known minimal invasive DHS technique and a more superior clinical results than the conventional technique ${ }^{12}$.

The main purpose of this study was to assess the variation of the novel radiological landmarks and angles between the right and left hip joints and different genders to constitute a guide line for surgeons who deal with proximal femoral surgery.
The general average values of the LTFCA + LTLFCA in the male and female populations were $\left(133.8^{\circ} \pm 5.09, \quad 135.2^{\circ} \pm 5.79\right)$ respectively. No statistical significance was detected between the two sides with $p=0.08$. The general average value of the LTFCA + LTLFCA in both genders and both sides was $134.5^{\circ} \pm 5.44$. These values are very much close to the standard DHS fixed angle which is $135^{\circ}$. This close values makes the newly described LTFCA + LTLFCA measurement applicable in proximal hip surgery.

In peritrochanteric surgery, many surgeons face difficulties in determining the exact point of entry despite using the angle guide with large incisions and this may lead to further muscle dissection and more trauma to the surrounding soft tissue, which in term increases the postoperative pain seriously and doesn't allow full-weight bearing and thus lowers the already lowered lower extremity motoric function of elderly patients ${ }^{10-12}$.

The most important point of this new angle method is, that in most cases you can determine the entry point of the guide pin on the lateral cortex without the use of angle guides, provides even a smaller wound size, less muscle dissection. On the other hand, it doesn't depend on equations to avoid magnification errors.

However this study has several weakness, The ( LTFCA) angle is sensitive to femoral rotations for that reason true AP is required for appropriate application. It is not applicable in patients with already diagnosed proximal femoral pathology; coxa valga and coxa vara.

\section{CONCLUSIONS}

The LTFCA + LTLFCA is an easy method that can facilitate trustable radiological landmarks for surgeons for a proper DHS insertion with a smaller incision and allows even little muscle trauma.

\section{REFERENCES}

1- Kay RM, Jaki KA, Skaggs DL. The effect of femoral rotation on the projected femoral neck shaft angle. J Pediatr Orthop 2000; 20: 736-9.

2- Beaule' PE, Allen DJ, Clohisy JC, Schoenecker $\mathrm{P}$, Leunig $\mathrm{M}$. The young adult with hip impingement: deciding on the optimal intervention. J Bone Joint Surg Am 2009; 91: 210-21.

3- Steppacher SD, Tannast M, Ganz R, Siebenrock KA. Mean 20-year follow up of Bernese periacetabular osteotomy. Clin Orthop Relat Res 2008; 466: 1633-44. 
4- Johnson LJ, Cope MR, Shahrokhi S, Tamblyn P. Measuring tip-apex distance using a picture archiving and communication system (PACS). Injury 2008; 39: 786-90.

5- Gnudi S, Ripamonti C, Lisi L, Fini M, Giardino R, Giavaresi G. Proximal femur geometry to detect and distinguish femoral neck fractures in postmenopausal women. Osteoporos Int 2002; 13: 69-73.

6- Crabtree N, Lunt M, Holt G, Kroger H, Burger

$\mathrm{H}$, et al. Hip geometry, bone mineral distribution and bone strength in European men and women:

The EPOS Study. Bone 2000; 27: 151-59.

7- Greendale GA, Young JT, Huang MH, Bucur A, Wang Y, Seeman T. Hip axis length in midlife Japanese \& Caucasians US residents: No evidence for an ethnic difference. Osteoporos Int 2003; 14: 320-25.

8- Tércio Henrique Soares de Farias, Vinícius Quadros Borges et al. Radiographic study on the anatomical characteristics of the proximal femur in Brazilian adults revbras ortop 2015; 50: 16-21.

9- Mourão AL, Vasconcellos HA. Geometria do fêmur proximalem ossos de brasileiros. Acta Fisiátrica 2001; 8: 113-18.

10- Russel T. Fracture of hip and pelvis. Crenshaw AH, editor. 8th ed., Campbell's operative orthopaedics, vol. 2, 8th ed. St. Louis, MO, USA: Mosby;1992; p. 896-915.

11- Gotfried Y. Percutaneous compression plating for intertrochanteric hip fractures: treatment rationale. Orthopedics 2002; 25: 647-52

12- Acar N, Harb A, Albaya A, Kaskin H. The clinical results of a novel method for minimal invasive dynamic hip screw fixation of intertrochanteric fractures compared to the conventional one. Eur J Trauma Emerg Surg 2016; 8, DOI:10.1007/s00068-016-0690-5. 